\title{
When A Workers' COOPERATIVE WORKS: The Case of Kerala Dinesh Beedi
}

\author{
G. Mitu Gulati* \\ T.M. Thomas Isaac** \\ William A. Klein***
}

The literature on worker cooperatives is dominated by explanations of why they do not work and why, accordingly, they are so rare. This Article presents a case study of a large worker cooperative in South India that has worked well for a long time. This cooperative illustrates, among other things, that worker control and worker democracy are not necessarily inconsistent with the degree of hierarchy and delegation that may be essential to effective operation. The cooperative has been able to compete despite paying wages and benefits that are dramatically higher than those paid by its competitors, while at the same time providing far better working conditions. How it has been able to do this is something of a puzzle. Part of the explanation is good fortune at its inception in attracting effective, honest, and dedicated managers and, subsequently, in avoiding government involvement and in being able to ignore cumbersome and unsuitable legal rules. Perhaps more important is the workplace culture and the ability to harness forms of mutual monitoring not available to competitors. At the end of the day, it is unclear how much of the success of the cooperative is a function of its cooperative nature and how much is a product of its unique circumstances. Still, the story of this enterprise offers useful lessons in the organization of economic activity, particularly in the importance of nonlegal mechanisms for maximizing individual cooperative productivity.

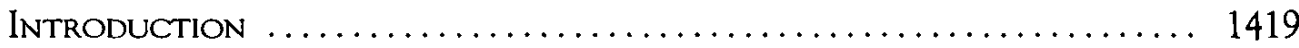

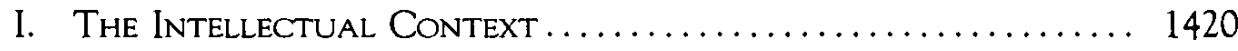

A. Why They Won't Work........................ 1422

* Professor of Law, UCLA School of Law; Visiting Professor of Law and Sloan Fellow, Georgetown University Law Center (2001-2002). We are grateful to Rick Abel, Steve Bainbridge, Margaret Blair, Devon Carbado, Vijay Dar, Heidi Li Feldman, Iqbal Gulati, Joel Handler, Eric Posner, Oliver Williamson, and participants at the 2001 Georgetown-Sloan Conference on Rents for comments. We owe a tremendous debt of thanks to the people at Kerala Dinesh Beedi who gave us many, many hours of their time and energy. We also owe a special debt to Devon Carbado for making this project come to fruition as part of the symposium. Finally, as always, Linda Karr O'Connor and the librarians at UCLA Law School provided us with superb research assistance.

** Professor of Economics and Fellow, Center For Development Studies, Thiruvananthapuram, India.

*** Maxwell Professor of Law Emeritus, UCLA School of Law; Visiting Professor of Law, Georgetown University Law Center (Fall 2001). 
1. Workers Are Inadequately Diversified ............. 1422

2. Workers Are Bad Bosses........................ 1423

3. Workers 'Will Be Locked in and There Will Be No ShareMarket Discipline......................... 1423

4. Workers Will Vote for Inefficient Compensation Systems . 1424

5. Workers Will Have Heterogeneous Goals, Which Will Lead to Inefficient Decisionmaking.................. 1424

6. Workers Face Higher Barriers to Raising Financial Capital............................. 1425

7. Workers Are Likely to Shirk and Will Not Provide Adequate Monitoring ......................... 1425

B. Why, Even If They Succeed Initially, They Will Degenerate .. 1426

1. Rich Workers Won't Share the Wealth and Will Become Capitalists Themselves ..................... 1426

2. There $W_{\text {ill }}$ Be Inadequate Long-Term Investments and Diversification ........................... 1426

3. The Second Generation Will Lack the Required Ideology . 1427

C. But We Know That Some Worker Cooperatives Enjoy LongTerm Success..................................... 1427

D. Finally, When They Work, What Will the Results Be? ...... 1428

1. Workers Will Be Happier and the Result Will Be Productivity Gains .......................... 1428

2. There Will Be Better Monitoring ................. 1429

3. Health Conditions Will Be Better................. 1429

4. There Will Be Less Opportunistic Behavior and Fewer Labor Disputes................................ 1429

5. Information-Sharing Will Lead to Better Decisionmaking and Team Production ........................ 1430

II. THE KDB StORY ................................ 1430

A. Origins and the Initial Source of Capital ............. 1430

B. Getting Past the Problems with Large-Scale Democratic Decisionmaking ............................... 1433

C. Supervisors' Relationships with Their Worker Bosses ........ 1436

D. Egalitarianism and the Resulting Conflicts ............. 1438

E. The Accumulation Puzzle ........................ 1440

F. The Productivity Gains from a Cooperative Structure........ 1442

1. Wages, Absences, and Turnover Rates.............. 1442

2. Labor Disputes, Monitoring, and Information-Sharing ..... 1444

3. Better-Quality Beedis........................ 1445

4. Other Sources of Savings .................... 1447

G. Diversification ............................... 1448

H. Degeneration ................................ 1449

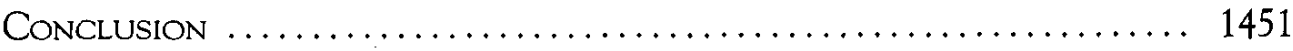




\section{INTRODUCTION}

This is the story of a large worker cooperative in southern India, Kerala Dinesh Beedi (KDB), which has achieved remarkable success for over thirty years. The heart of the story of this organization is an almost unbelievable improvement in working conditions and wages. That is a fascinating and inspiring human-interest story that has been told elsewhere. ${ }^{1}$ The focus of this Article, however, is on the structures and mechanisms that account for its success, despite the apparently heavy odds against such success in a worker-controlled firm. We will show how such a firm was able to achieve the following, seemingly inconsistent objectives:

1. Effective management of human resources through voluntary delegation of control within a hierarchical management structure.

2. Effective competition against capital-controlled enterprises.

3. An essentially egalitarian wage structure, top to bottom.

4. Worker democracy, not just at the shop-floor level, but at all levels.

5. Accumulation of capital and preservation of the long-term viability of the firm.

From all of this, we draw insights into certain aspects of social and economic organization:

1. The importance of social and political background.

2. The irrelevance, or even the possibly pernicious effect, of legal rules and government regulation.

3. The importance of informal mechanisms for maintaining worker and manager commitment and efficiency.

As we describe more fully below, the KDB cooperative has a number of unique characteristics. It began with a large group of experienced workers who had lost their jobs when their employers moved elsewhere in response to what the employers perceived as unreasonable worker demands. The workers, who became the worker members of the cooperative, lived in relatively close proximity to one another; presumably, they shared important values and were able to impose informal sanctions on one another both at the work site and in the community. The workers all performed the same simple tasks. They made beedis - a cheap handrolled cigarette that is widely consumed among the lower strata of the working class in India. The job requires no tools other than a lap tray and a pair of scissors. The workers were from the Kannur region of the southern state of Kerala, a region that

1. This story is detailed in T.M. Thomas Isaac et al., Democracy at Work in an Indian Industrial CoOperative: The Story of Kerala Dinesh BeEdi (1998). 
was, and continues to be, a stronghold of the Marxist political party. The start-up capital for KDB was provided by the state, but the state then stayed out of the picture for the most part. A change in these background facts might well have doomed the cooperative to the failure that has characterized most other attempts to organize worker cooperatives. Despite these unique background characteristics, however, important general lessons can be learned from the KDB story.

Before telling the story, we describe in Part I the conventional thinking about worker cooperatives and about why they almost never achieve longterm success. Part I also describes some of the presumed benefits of a successful worker cooperative. Part II tells the KDB story and links it to the predictions and claims described in Part I. Part III concludes with a discussion of some of the insights from the study. Part III is followed by tables that match the hypotheses from the literature to the facts of the KDB case. ${ }^{2}$

\section{The Intellectual Context}

According to most of the existing writing on worker cooperatives, they are unlikely to succeed: The few successful worker cooperatives will likely be transformed into standard capital-controlled structures, and the tiny number that are not transformed will be in a narrow set of industries. ${ }^{3}$

2. Before proceeding, a few words of background on the project may help. Our interest in this project was the result of a series of conversations that we had about Kerala Dinesh Beedi (KDB) subsequent to the publication of Democracy at Work by T.M. Thomas Isaac, Richard W. Franke, and Pyaralal Raghavan in 1998. See id. That study provides both a detailed description and institutional analysis of the circumstances leading to the inception of KDB in 1969 and its evolution up to 1997. Despite the rich detail that it provides, a question that the book only touches upon briefly is how $\mathrm{KDB}$, despite its cooperative structure and high levels of compensation, has been able to survive and, on certain fronts, even to outcompete the more traditional capitalist firms that dominate the beedi industry. The book does have a chapter with an efficiency analysis, but that examines the comparative efficiencies of the different primary societies within KDB. See id. at 156-81. In contrast, we address the question of how KDB has been able to compete with other firms that produce the same product. In attempting to set forth an analysis of this question, we have relied both on the background research that Isaac and his coauthors did for their book and a set of subsequent interviews that we conducted at KDB in 2000 and 2001. Part II.A-B of our Article draws largely upon Isaac's prior research; interested readers will be able to find greater detail on these matters in the book that arose from that research. See id. Part II.C-H is largely based on the interviews that we conducted in 2000 and 2001.

3. See generally, e.g., Michael Kremer, Why Are Worker Cooperatives So Rare? National Bureau of Economic Research, Working Paper No. 6118 (July 1997) http:/papers.nber.org/papers/ w6118.pdf; Jon Elster, From Here to There; or, If Cooperative Oumership is So Desirable, Why are There So Few Cooperatives? 6 Soc. Phil. Poly 93 (1989). For surveys of the literature, see, for example, Alan Hyde, In Defense of Worker Ownership, 67 Chi.-Kent. L. Rev. 159 (1991) (observing that the economics, legal, and political science literature generally answers the question of "When Does Worker Ownership Work?" in one of two ways: "always" or "never"); Gregory Dow, Gov. erning the Firm: Economic Theory and Worker Control (unpublished manuscript, dated 2001, on file with the authors) (reviewing the literature and noting the focus on theoretical explanations for why worker control usually leads to failure). 
The evidence discussed in the bulk of the literature on worker-run enterprises is from Europe and North America. ${ }^{4}$ The most discussed examples are those of the Mondragon enterprises in the Basque region in Spain and the plywood cooperatives in the Pacific Northwest region of the United States. ${ }^{5}$ More recently, there has been some discussion and study of employee stock ownership plans in the United States, but while these bear some similarities to worker cooperatives, they are different in important respects. ${ }^{6}$

A worker cooperative, for our purposes, is an economic enterprise in which the workers have both the exclusive control rights and the exclusive claims to the firm's residual earnings. Further, the residual interests and control rights are distributed equally among the workers and are possessed by

4. Much of the recent literature has focused on cooperative enterprises in Italy, France, Britain, and Spain. See, e.g., Piero Ammirato, La Lega: The Making of a Successful Cooperative Network (1996); Will Bartlett et al., Labor-Managed Cooperatives and Private Firms in North Central Italy: An Empirical Comparison, 46 Indus. \& LAB. Rel. REV. 103 (1992); Saul Estrin \& Derek C. Jones, The Viability of Employee Ouned Firms: Evidence From France, 45 Indus. \& LAB. Rel. Rev. 323 (1992); Derek C. Jones \& David K. Backus, British Producer Cooperatives in the Footwear Industry: An Empirical Evaluation of the Theory of Financing, 87 ECON. J. 488 (1977); Silvia Pittatore \& Gilberto Turati, A Map of Property Rights in Italy and the Case of Co-operatives: An Empirical Analysis of Hansmann's Theory, 3 ECON. ANALYSIS 23 (2000). For a recent invocation of the Mondragon experience in the legal literature, see Lawrence E. Mitchell, Corporate Irre. SPONSIBILITY 242-245 (2001).

5. On the Mondragon, see generally Keith Bradley \& Alan Gelb, CoOperation at Work: The Mondragon Experience (1983); William Foote Whyte \& Kathleen King Whyte, Making Mondragon: The Growth and Dynamics of the Worker Cooperative COMPLEX (1988); Keith Bradley \& Alan Gelb, Cooperative Labour Relations: Mondragon's Response to Recession, 25 BRIT. J. INDUS. ReL. 77 (1987); William F. Whyte, The Mondragón Cooperatives in 1976 and 1998, 52 Indus. \& LAB. Rel. Rev. 478 (1999). On the plywood cooperatives, see generally Ben Craig \& John Pencavel, The Behavior of Worker Cooperatives: The Plywood Companies of the Pacific Northwest, 82 Am. ECON. Rev. 1083 (1992); Ben Craig \& John Pencavel, Participation and Productivity: A Comparison of Worker Cooperatives and Conventional Firms in the Plywood Industry, in Brookings Papers on ECONOMIC ACtivity: Microeconomics 121 (Martin Baily et al. eds., 1995).

6. Generally, in firms with employee stock option plans (ESOPs) there is nonworker ownership of some of the equity, and control rights are based on stock ownership rather than worker status. Moreover, ESOPs lack the egalitarian pay structure that is the mark of a true worker cooperative. For recent research discussing ESOPS, see generally Margaret M. Blair, et al., Employee Oumership: An Unstable Form or a Stabilizing Force?, in The New Relationship: Human Capital In THE American Corporation 241 (Margaret M. Blait \& Thomas A. Kochan eds., 2000); Joseph Blasi et al., Employee Stock Oumership and Corporate Performance Among Public Companies, 50 INDUS. \& LAB. ReL. Rev. 60 (1996); Brett McDonnell, ESOP's Failures: Fiduciary Duties When Managers of Employee-Oumed Companies Vote to Entrench Themselves, 2000 Cólum. Bus. L. Rev. 199. For a report on the status of ESOPs in the United States, see PAMEl.A PERUN, URBan INSTI. tute, Employee Stock Ownership Plans: A Status Report, Brief No. 10, (2000). Jeffrey Gordon's recent work has brought particular attention to the workings of the ESOP at United Airlines. See generally Jeffrey N. Gordon, Employee Stock Ownership in Economic Transitions: The Case of United and the Airline Industry, in EMPLOYEes AND CORPORATE GOVERNANCE 317 (Margaret M. Blair \& Mark J. Roe eds., 1999). 
all or almost all of the workers (especially those at the lowest rungs of the organization's hierarchy). In other words, a worker cooperative is egalitarian and democratic. Thus, the typical large U.S. corporate law firm-in which a subset of senior lawyers (the partners, and, in many firms, the senior partners alone) make all the important decisions and receive the residual earnings, while lower-level lawyers and support staff are wage employees-would not fit our definition of a worker cooperative.?

Worker cooperatives are appealing in many ways, but they are rare. Over the years, various studies have identified a number of reasons (a) why they won't work and (b) why, even if they succeed initially, they will degenerate.

\section{A. Why They Won't Work}

The literature on worker cooperatives identifies various obstacles to success. We divide these into the seven categories summarized briefly below.

\section{Workers Are Inadequately Diversified}

Workers' investment in their productive human capital is likely to be a large part of their total wealth, and they have no practical way to achieve diversification. Thus, goes the argument, they will prefer a highly conservative business strategy. Such a strategy will, at least in the long run, result in an inability to compete effectively with firms controlled by shareholders, who can diversify their investments and direct their managers to adopt possibly risky strategies that are relatively more effective in the long run. ${ }^{8}$ Thus, over time, shareholder-controlled firms will outcompete worker-controlled firms and drive the latter out of business. ${ }^{9}$ Worker-controlled firms will suffer a similar disadvantage in competition with wealthy capitalist individuals and families of the type commonly found in India and other less-developed

7. These are described in David B. Wilkins \& G. Mitu Gulati, Reconceiving the Toumament of Lawyers: Tracking, Seeding, and Information Control in the Internal Labor Markets of Elite Law Firms, 84 VA. L. REV. 1581 (1998).

8. See Samuel Bowles \& Herbert Gintis, Credit Market Imperfections and the Incidence of Worker-Owned Firms, 45 MEtroeconomica 209, 215 (1994) (arguing that because workers are risk-averse and lack diversification, the firms that they control will select relatively conservative investment projects).

9. For articulations of this argument, see Stephen M. Bainbridge, Participatory Management Within a Theory of the Firm, 21 J. CORP. L. 657, 667 (1996) (making the point about the differing nature of employee and shareholder claims to the earnings of the firm and the likely differences in risk preferences between the groups); Avner Ben-Ner, The Life Cycle of Worker-Owned Firms in Market Economies, 10 J. Econ. Behav. \& Org. 287, 290-91 (1988) (same); John P. Bonin et al., Theoretical and Empirical Studies of Producer Cooperatives: Will Ever the Twain Meet?, $31 \mathrm{~J}$. EcoN. LITERATURE 1290, 1316 (1993) (concluding that the inability of the members of labor-controlled enterprises to diversify their interests adequately is a major reason for the rarity of such enterprises). 
economies. ${ }^{10}$ Such individuals or families are likely to have diversified holdings. It is these types of firms with which the KDB cooperative competes.

2. Workers Are Bad Bosses

In a worker cooperative, the workers hire managers to supervise them. The supervisors, knowing that they are dependent on the workers for promotions and job security, will have an incentive to please their worker bosses. The prediction is then made that there will be a reluctance on the part of the supervisors to impose penalties when needed and a willingness to confer rewards even when they are not warranted. In other words, managers are likely to indulge in excessive pandering. In a traditional corporate structure, there is no reason for such concern; the managers generally have the right incentives, as well as the power, to impose appropriate penalties and to confer rewards. In some capital-controlled firms, workers may be able to complain about unjust treatment by supervisors. But the workers are unlikely to have the right to fire their supervisors because they do not like the way that they are treated. ${ }^{11}$

\section{Workers Will Be Locked in and There Will Be No Share-Market Discipline}

In contrast to shares of public corporations, cooperative interests are generally nontransferable (or severely restricted in their transferability). This is said to produce at least two inefficiencies. First, the lack of an active market in the firm's securities means that there is no external market mechanism to impose discipline. ${ }^{12}$ This supposedly will result in inefficiency in operation. Second, workers in a worker cooperative benefit from the accumulated capital of the firm. Each worker can be thought to have a pro rata claim on the assets of the firm, but the worker loses the claim if he or she

10. On the differences in control characteristics across countries, see generally Rafael La Porta, et al., Corporate Ounership Around the World, 54 J. Fin. 471 (1999).

11. For arguments that workers are not equipped for self-management, see generally Armen A. Alchian \& Harold Demsetz, Production, Information Costs, and Economic Organization, 62 АM. ECoN. Rev. 777 (1972); Derek C. Jones, British Economic Theory on Associations of Laborers, 1848-1974, 47 Annals Publ. \& Cooperative Econ. 5 (1976). The following language from Sidney Webb and Beatrice Webb is often quoted:

The relationship set up between a manager who has to give orders all day to his staff, and the members of that staff who, sitting as a committee of management, criticise his action in the evening, with the power of dismissing him if he fails to conform to their wishes, has been found by experience to be an impossible one.

Sidney Webb \& Beatrice Webb, A Constitution For The Socialist Commonwealth of Great Britain 161 (1920).

12. See William A. Klein \& John C. Coffee, Jr., Business Organization and Finance 176-207 (7th ed. 2000) (discussing the effects of share market-discipline). See also Oliver Hart \& John Moore, Cooperatives vs. Outside Ownership, National Bureau of Economic Research, Working Paper No. 6421, (1998) (discussing this argument), http://paper.nber.org/papers/w6421.pdf. 
leaves the firm. Because they are locked into their capital contributions, workers cannot move to their optimal points of productivity. The result is inefficient lock-in-the workers in place may not be the best ones for the job. Obviously, this problem diminishes if workers have tradable membership rights. At $\mathrm{KDB}$, however, the membership rights are not tradable.

\section{Workers Will Vote for Inefficient Compensation Systems}

This argument claims that workers in a worker cooperative will likely vote to decide on compensation and that the resulting compensation structure will reflect the interests of the median worker. Over time, this pattern will likely result in a compensation structure that transfers from the highly productive to the less productive, that is, an egalitarian compensation structure. ${ }^{13}$ That, in turn, will mean that the more productive workers either will shirk or will not join the cooperative in the first place. Put differently, there is likely to be an adverse selection effect with the result that the less productive and lazier workers flock to the cooperative. ${ }^{14}$

\section{Workers Will Have Heterogeneous Goals, Which Will Lead to Inefficient Decisionmaking}

Diversified shareholders are likely to have a single goal: maximizing profits. Workers, in contrast, will inevitably have a wide variety of goalswages, pensions, health benefits, child care, furthering political causes, etc.-that will differ from worker to worker. The inevitable disparity of goals that will arise in a large worker-run cooperative will, it is said, generate wasteful conflicts. In addition to the time wasted on disputes, decisionmaking itself will be slowed. This can have harmful effects on the firm's competitiveness in that the firm will be slower to respond to changes in the outside product market. A more traditional firm, in contrast, will have delegated

13. See Kremer, supra note 3. For a discussion of the sorting dynamic in partnerships, see Joseph Farrell \& Suzanne Scotchmer, Partnerships, 103 Q. J. Econ. 279 (1988). In contrast, Henry Hansmann points out that gearing payment schemes to the preferences of the median worker may be better from an efficiency point of view in which the median worker's preferences are likely to be closer to the average than are the marginal worker's preferences (because the efficiency point is where the average worker's preferences are). See Henry Hansmann, When Does Worker Ownership Work? ESOPs, Law Firms, Codetermination, and Economic Democracy 99 YALE L.J. 1749, 1767-68 (1990). The key here, of course, is the distribution of worker preferences. The impact of the distribution of worker preferences on voting and, therefore, efficiency, is also the subject of Hart and Moore's 1998 working paper. See Hart \& Moore, supra note 12.

14. See Stephen C. Smith, Book Review, 27 J. Comp. ECON. 576, 577 (1999) (reviewing ISAAC ET AL., supra note 1) (observing the adverse selection mechanism that may be at play at KDB because of the higher levels of maternity benefits that it offers, which may attract women workers who are focused on having children). 
the authority regarding the relevant decisions and will be able to respond quickly. ${ }^{15}$

\section{Workers Face Higher Barriers to Raising Financial Capital}

As compared to investors in capital-controlled firms, workers are unlikely to have much financial capital. In economies where worker-controlled firms are rare, financial institutions may be reluctant to lend money to such enterprises. ${ }^{16}$ In situations of credit-rationing, this may mean that the enterprise is not able to raise capital at all. The difficulty of raising initial capital, therefore, presents a barrier to these enterprises getting off the ground. ${ }^{17}$ Assuming that the enterprise does get started, financing new projects may be difficult. Lenders may be more reluctant to lend to workerrun enterprises because of heightened levels of (a) moral hazard and (b) transactions costs. The moral hazard argument is that lenders bear most of the risk of failure in situations in which workers can easily move to new jobs in the event of the firm's failure. As for the higher transactions costs, the argument is simply that it is easier and quicker to deal with a single borrower (or the borrower's delegate who has authority) than to deal with a group that has to use a democratic process to make decisions. ${ }^{18}$

\section{Workers Are Likely to Shirk and Will Not Provide Adequate Monitoring}

In a large egalitarian enterprise, in which compensation is a function of what others produce, there is a free rider problem. Given that their impact on total production is likely to be small, individual workers not only have an

15. These arguments have been made most forcefully by Hansmann. See generally HENRY Hansmann, The OWNershiP OF ENTERPRise (1996); Henry Hansmann, The Viability of Worker Ounership: An Economic Perspective on the Political Structure of the Firm, in THE FIRM AS A NEXUS OF Treaties 162 (Masahiko Aoki et al. eds., 1990). For similar arguments, see also Lee Benham \& Philip Keefer, Voting in Firms: The Role of Agenda Control, Size and Voter Homogeneity, 29 EcoN. INQUIRY 706 (1991).

16. See Ben-Ner, supra note 9, at 290.

17. See Jacques H. Drèze, Self-Management and Economic Theory: Efficiency, Funding, and Employment, in Market Socialism: The Current Debate 253, 257-62 (Pranab K. Bardhan \& John E. Roemer eds., 1993); Connel Fanning \& Thomas McCarthy, Hypotheses Concerning the Non-viability of Labour-Directed Firms in Capitalist Economies, 17 ECON. ANALYSIS \& WORKERs' MGMT. 123, 137 (1983).

18. On the subject, see generally Benedetto Gui, Limits to External Financing: A Model and an Application to Labor-Managed Firms, in 1 AdvanCES IN THE ECONOMIC ANAlysis OF PARticipatory and Labor-Managed Firms: A Research Annual 107 (Derek C. Jones \& Jan Svejnar eds., 1985) (describing the moral hazard problem); Henry M. Levin, ESOPs and the Financing of Worker Cooperatives, in WORKER COOPERATIVES IN AMERICA (Robert Jackall \& Henry M. Levin eds., 1984); Herbert Gintis, Financial Markets and the Political Structure of the Enterprise, $11 \mathrm{~J}$. ECON. Behav. \& ORG. 311 (1989) (describing the problems of transactions costs when dealing with a democratically run borrower); and Oliver Hart \& John Moore, A Theory of Debt Based on the Inalienability of Human Capital, 109 Q. J. ECON. 841 (1994) (similar). 
incentive to shirk in their own work but also are unlikely to expend resources in monitoring others. ${ }^{19}$

\section{B. Why, Even If They Succeed Initially, They Will Degenerate}

Here, there are three dominant explanations.

\section{Rich Workers Won't Share the Wealth and Will Become Capitalists Themselves}

The argument is that if a group of workers succeeds and the firm accumulates a significant amount of capital, the workers will likely be unwilling to share their bounty. To the extent that the founders need additional labor, they are likely either to hire employees or to contract the work out. After all, why share the capital that one has earned? Put differently, the logic of economic self-interest suggests that a successful cooperative will necessarily transform into a corporate structure in which some workers have equity claims and control, but others are pure wage workers. ${ }^{20}$

A related problem arising from the accumulation of wealth within the firm is that in good times the cooperative members will be reluctant to expand (by taking in new worker members), because they will not wish to share the wealth.

\section{There Will Be Inadequate Long-Term Investments and Diversification}

Another prediction in the literature is based on the assumption that workers have limited time horizons. The workers will focus on maximizing the gains that they can obtain within their lifetimes. They have no owner-

19. For arguments along these lines, see Alchian \& Demsetz, supra note 11, at 782 (arguing that there is a need to have a residual claimant (assumed to mean a nonworker) who has an incentive to monitor the others); Bengt Holmstrom, Moral Hazard in Teams, 13 BeLl J. ECON. 324, 327 (1982) (describing how, under certain conditions, group bonuses or penalties can be used to obtain efficient effort levels); Michael C. Jensen \& William H. Meckling, Rights and Production Functions: An Application to Labor-managed Firms and Codetermination, 52 J. Bus. 469, 485-88 (1979) (arguing that because workers' share in profits is diluted in worker-run firms, members' and supervisors' incentives to monitor are diminished). These articles tackle the problems that arise with teams in which there is joint production and individual effort is not verifiable. At KDB, production is individualistic in that each beedi worker rolls his or her own beedis. Nevertheless, there is an interdependence among the workers in that the workers depend on each other to maintain a high quality of production-something that is almost impossible to verify.

A different version of the hypothesis that cooperatives offer inadequate incentives to monitor is that workers will not take adequate care of their fixed assets (machinery and the like) because these are commonly owned. See Dow, supra note 3.

20. For explications of this "degeneration" argument, see Avner Ben-Ner, On the Stability of the Cooperative Type of Organization, 8 J. Comp. ECon. 247 (1984); Kevin Davis, Credit Union Governance and Survival of the Cooperative Form, 19 J. FIN. Services RES. 197, 197 (2001); Hajime Miyazaki, On Success and Dissolution of the Labor-managed Firm in the Capitalist Economy, 92 J. PoL. ECON. 909 (1984). 
ship interest that they can sell at a market price or leave to their heirs. Thus, they will be averse to long-term investments and will be eager to remove capital from the enterprise before they retire. ${ }^{21}$ They will also be averse to diversification and technological innovation because the benefits of diversification and innovation will accrue in large part to later generations of workers. This may not be a problem in the short term, but will lead over time to decay, absent conversion to a capital-controlled form. ${ }^{22}$

\section{The Second Generation Will Lack the Required Ideology}

A final prediction arises from the fact that the first generation of workers, perhaps because of a prior struggle against capitalists, is likely to be ideologically committed to the notion of sharing. The next generation, not having participated in the initial struggle, is unlikely to have a similar commitment. Therefore, they will push the structure of the enterprise towards a traditional capital-dominated structure..$^{23}$

\section{But We Know That Some Worker Cooperatives Enjoy Long-Term Success}

Despite all the reasons for failure or degeneration, some worker cooperatives have thrived for long periods of time. The explanation generally offered is that they are likely to be limited to certain industries. These will be rare, unique industries in which the problems described above are obviated-in which there are unique benefits to be gained from worker domination. For example, these are likely to be industries in which monitoring is easy, workers have homogenous goals, and capital requirements are low. ${ }^{24}$ Or, as in the case of law firms in the United States, there may even be regulations that require worker domination. What one will see, therefore, is that the successful worker cooperatives are clustered in a few industries. ${ }^{25}$

There is also a "culture" variant of this argument, which maintains that there are particular regions with cultures that value participatory democracy

21. This is often referred to as the "accumulation" problem. On the subject, see generally Jaroslav Vanek, The Labor-Managed Economy: Essays By Jaroslav Vanek (1977).

22. For discussions of what is often referred to as the "horizon problem," see Eirik G. Furubotn, The Long-Run Analysis of the Labor-Managed Firm: An Alternative Interpretation, 66 AM. ECON. REV. 104, at 111-15 (1976); Hansmann, supra note 13, at 1774; Jensen \& Meckling, supra note 19 .

23. On what is sometimes referred to as the "iron law of oligarchy," see JOYCE ROTHSCHILD \& J. Allen Whitt, The Cooperative Workplace: Potentials and Dilemmas of Organiza. tional Democracy and Participation 128 (1986). See also Mayer N. Zald \& Roberta Ash, Social Movement Organizations: Growth, Decay and Change, 44 Soc. ForCEs 327, 328, 332 (1966).

24. For variants on this argument about clustering, see Hansmann, supra note 13; Dow, supra note 3 .

25. See Bainbridge, supra note 9, at 717-18; Ben-Ner, supra note 9, at 297; Benham \& Keefer, supra note 15. 
at the workplace more than others. Places that strongly exhibit a commitment to participatory democracy are likely to be uniquely hospitable to worker cooperatives. ${ }^{26}$

\section{Finally, When They Work, What Will the Results Be?}

While there is an extensive literature on why worker-run enterprises do not work, there is relatively little discussion of why politicians, policymakers, and scholars in many parts of the world find such enterprises to be so appealing. What is the basis for that appeal? What are the gains that supposedly accrue from having a worker-run enterprise? In part, the appeal of worker cooperatives rests on social and political considerations, such as the belief that cooperatives lead to a more egalitarian society, produce greater autonomy, or generate greater levels of political awareness and participation. ${ }^{27}$ Because of the nature of our single case study, however, we restrict our focus to the economic rationales favoring cooperatives. Thus, we next turn to the efficiency gains that are thought to accrue from cooperatives. Again, the ideas that follow are those that one encounters in the existing literature (very briefly summarized) and are not necessarily ones that we endorse.

\section{Workers Will Be Happier and the Result Will Be Productivity Gains}

The argument is a simple efficiency wage story. Workers in a cooperative, in which they control what happens, are likely to be happier and to have more positive feelings towards the enterprise than would workers in a more traditional firm in which they have no control and are subject to the whims of the managers. These happier workers will work harder and cooperate better in teams. The result will be significant productivity gains. ${ }^{28}$

\footnotetext{
26. See Bainbridge, supra note 9; Dow, supra note 3.

27. For a review of this literature, see Dow, supra note 3.

28. A number of studies have reported positive correlations between the level of worker participation and economic performance. See, e.g., JuAN G. Espinosa \& ANDREW S. Zimbalist, EConomic Democracy: Workers' Participation in Chilean Industry 1970-1973, at 141-75 (1978); Saul Estrin et al., The Productivity Effects of Worker Participation: Producer Cooperatives in Westerm Economies, $11 \mathrm{~J}$. Comp. Econ. 40 (1987). The classic efficiency wage story about happier workers giving gifts to the firm is in George A. Akerlof, Labor Contracts as Partial Gift Exchange, 97 Q.J. ECON. 543, 550 (1982). For arguments that participation and residual claim rights instill pride in workers and improve their productivity, see Michael Conte, Participation and Performance in U.S. Labor-Managed Firms, in Participatory and Self-Managed Firms: Evaluating Economic PerformanCe 213 (Derek C. Jones \& Jan Svejnar eds., 1982); Samuel J. Davy, Employee Ounership: One Road to Productivity Improvement, J. Bus. StRategY 12 (Summer 1983). A different version of the efficiency wage story that Hyde tells, that also favors the cooperative structure, is that higher levels of trust enable the firm to tie wages more directly to productivity than would be possible in a situation where workers do not trust the evaluations of productivity made by the owners of the firm. See Hyde, supra note 3, at 200.
} 


\section{There Will Be Better Monitoring}

In contrast with dispersed shareholders, workers will be better monitors of managers. In addition, because of their larger stake in the enterprise, workers will also be more likely to monitor each other than they would in a more traditional enterprise. The result will be lower levels of shirking, as well as of corruption. ${ }^{29}$

\section{Health Conditions Will Be Better}

Workers may be reluctant or unable to bargain for adequate health benefits because of signaling or other problems. In a worker-run enterprise, workers decide on the level of benefits that will serve their long-term interests best. Healthier workers will be stronger, absenteeism will be reduced, and productivity will benefit. ${ }^{30}$

\section{There Will Be Less Opportunistic Behavior and Fewer Labor Disputes}

There will be resource savings because the workers will not have the same need to protect against opportunistic behavior on the part of managers as they would in a more traditionally structured firm. For example, workers will not have to fear management attempts to extract wage concessions by asserting the presence of nonexistent problems with the firm's competitiveness. Similarly, one would expect to see fewer labor disputes in a worker-run enterprise, because the workers are likely to have greater respect for, and faith in, the managers whom they have hired. ${ }^{31}$

29. See Ben-Ner, supra note 9, at 293-94 (arguing that heightened mutual monitoring is likely to take place at a worker-run firm); Hansmann, supra note 13, at 1762-63 (discussing the argument, but criticizing the variant of it, that worker control and participation occur primarily in response to the problem of mutual monitoring); Dow, supra note 3 (discussing evidence on heightened levels of mutual monitoring at worker-run enterprises).

30. On the points that health and safety conditions at a worker-run enterprise are likely to match up better with the worker's long-term interests than they would in a capitalist firm and that the former will result in lower turnover and absentee rates, see Richard L. Abel, A Socialist Approach to Risk, 41 MD. L. Rev. 695, 737-40 (1982); cf. Sarah Brown et al., Absenteeism and Employee Sharing: An Empirical Analysis Based on French Panel Data; 1981-1991, 52 Indus. \& LAB ReL. REv. 234 (1999) (examining the relationship between employee profit-sharing and absenteeism).

31. See Ben-Ner, supra note 9, at 292; see also Hyde, supra note 3, at 191-94 (making a trust-based argument for employee participation); Marleen A. O'Connor, A Socio-Economic Approach to the Japanese Corporate Governance Structure, 50 WASH. \& LeE L. ReV. 1529, 1533 (1993) (arguing that there is likely to be a greater level of trust if there is employee involvement in management). For an examination of the types of participation arrangements that can produce the efficiency-enhancing environments of trust, see generally David I. Levine $\&$ Laura D'Andrea Tyson, Participation, Productivity, and the Firm's Environment, in PAying FOR Productivity: A Look AT THE EVIDENCE 183 (Alan S. Blinder ed., 1990). 
5. Information-Sharing Will Lead to Better Decisionmaking and Team Production

It is often argued that worker participation in management decisions leads to improved information-sharing between management and lower-tier workers, resulting in better decisionmaking. ${ }^{32}$

Before proceeding, we offer a caveat. In the foregoing part, our goal was to set out the basic arguments for why cooperatives do or do not work. In culling these arguments from the articles that we cite, we have oversimplified and have not done adequate justice to the nuanced arguments in many of the articles.

\section{THE KDB STORY}

The case study that follows is based largely on a series of interviews and site visits that two of the authors conducted over the past year. In addition, five years earlier, one of the authors had extensively studied KDB for a different project.

\section{A. Origins and the Initial Source of Capital}

KDB has its origins in a 1965 conflict between the beedi workers in the Kannur region and the owners of large firms in the business of making and selling beedis. Before this time, a large fraction of the beedi rollers worked on company-owned sites. The owners, claiming that profits had declined, sought to move to a strict piecework method of compensation. In addition, the owners sought to organize production through middlemen who would hire, or buy from, small groups of workers and sell to the company owners. (Such contracting and piecework compensation now comprise the dominant system for beedi production in the rest of India.) The workers believed, with good reason, that the result would have been lower wages and increased difficulty in organizing. At the same time, the Kerala government had expressed its intention to begin enforcement of an existing minimum wage law that had been mostly ignored. The new system supported by the company owners would have made enforcement virtually impossible.

Some workers also believed that there were other, more pernicious motives at play-particularly, that the owners were seeking to avoid government regulation of the workplace. Among other things, it was claimed, the owners feared the leftist state government in Kerala would take a hard line on child labor. Children, because of their delicate fingers, are among the best beedi rollers. With centralized, vertically integrated workplaces, enforcement of prohibitions on child labor might have been feasible. Under a

32. See generally Carla O'Dell, People, Performance, and Pay (1987). 
highly dispersed contracting-out system, the independent middlemen would contract out the work to families and pay the adults for the work of their children; enforcement of any child labor laws would be, as with the minimum wage, virtually impossible.

The workers, represented mostly by leftist unions, refused to accept proposals to move to the contracting-out system. In response, the owners threatened to move their operations elsewhere-to the nearby state of Karnataka where the workers were thought to be less well-organized and, as a result, more pliable. This would mean that twelve thousand beedi workers in the Kannur area would lose their jobs. Kerala had just elected a leftist government for the first time, and the last thing that the government wanted in the early part of its tenure was large-scale unemployment. The owners, with the support of the powerful opposition parties, also claimed that one of the primary reasons for the owners' threat to leave Kerala was the government's support of labor unrest (and, conversely, its lack of support for the owners' interests). Indeed, the labor unrest was being cited as a reason why the federal government should dismiss the local state government (which the central government might lawfully have been able to do under certain conditions).

Government officials made numerous efforts to broker a settlement between the worker representatives and the owners, but none worked and the owners made good on their threat to pack up and leave. The result was the feared massive unemployment.

The workers had previously made at least two different attempts to set up substitute enterprises. Both had failed. The problems with these initial efforts included inadequate capital, the use of low-quality material, and inadequate distribution networks. The beedis that were produced were substandard, and delays caused by the inadequate distribution system made things worse by causing the beedis to become stale. The market refused to accept these beedis. With KDB, things were desperate. A number of workers were already rumored to be rolling beedis at home for contractors, who were in turn supposedly selling the beedis to the erstwhile factory owners. The Kerala government then stepped in and agreed to make 50 percent of the initial capital contribution for a worker cooperative. The government not only contributed Rs 1,350,000, but also loaned each worker Rs 19 of the Rs 20 that had been set as the initial capital contribution by each worker. (At the time, beedi workers were earning approximately Rs 3 per day.) The Industries Minister, who was a veteran trade union worker, moved to Kannur and set up camp there for two months to help recruit workers and to set up the basic structure of the enterprise.

A team of specialists on industrial cooperatives was asked to draft a set of bylaws for the enterprise. Having set things up in conjunction with the 
various worker trade union factions, the government then showed unusual restraint and withdrew from any active role in the running of the cooperative. The cooperative had at its head a five-member board of directors, all of them respected beedi workers. In addition, there were two nonvoting members from the government: the president and the secretary. While they were nonvoting members of the board, the president and the secretary were extremely powerful, because they were the representatives of the government and the government under the law relating to cooperatives could impose a number of burdensome rules and regulations. The president was, by a stroke of good fortune, an effective and well-regarded official who had prior experience in working with worker cooperatives. As it turned out, he headed KDB for nearly thirty years and is a revered figure at $\mathrm{KDB}$.

Given the prior failures to establish a worker cooperative and the perception that those failures were caused by inadequate quality controls, the primary concern of the founders of $\mathrm{KDB}$ was the production of a high-quality product. In particular, efforts were made to be careful with the quality of materials used. Spending capital on high-quality raw materials, however, meant that there was little left for advertising and publicity. KDB products were already more expensive than those of their competitors. For marketing, $\mathrm{KDB}$ relied on word of mouth. Groups of $\mathrm{KDB}$ workers were organized to try to persuade other workers (including those at competitor beedi manufacturing units) to buy their beedis as a sign of support. Ironically, what helped $\mathrm{KDB}$ the most at this point was one of the moves by the owners who had moved away. KDB had named its product "Dinesh Beedi." These owners, whose brand was named "Ganesh Beedi," brought an action in court alleging that the name Dinesh was essentially the same as Ganesh and that this was a trademark violation. KDB's supporters used this to reinforce the image of the evil capitalist owners trying to squash the poor workers. Something worked, and KDB's beedis sold.

In sum, KDB got its start through a combination of initial government funding, popular support, a dedicated group of founders, and luck. The solution to the problem of raising the initial capital was the government's vital contribution at the outset. The usual problems (at least in India) of government interference and corruption and the imposition of inefficient bureaucratic controls were likely avoided because, given the sudden and massive unemployment, the government officials (who were initially leftist but moved more to the right soon thereafter) were desperate to have the venture succeed. Today, government interference remains minimal for two reasons. First, $\mathrm{KDB}$ is no longer dependent on the government for capital infusions. Second, $\mathrm{KDB}$ is one of the few successful government-initiated ventures in 
the state. The risk that any interference might cause failure is one that none of the governments since 1969 has been willing to take. ${ }^{33}$

\section{B. Getting Past the Problems with Large-Scale Democratic Decisionmaking}

The image of worker cooperatives in much of the literature is one of frequent meetings and elections, and continual efforts to achieve consensus. Indeed, this image is consistent with the formal laws governing $\mathrm{KDB}$. With a large and heterogeneous workforce, this democratic, consensus-building decisionmaking process is thought to lead inevitably to inefficient operations. But this expectation rests on the assumption that the workers in any large organization will have heterogeneous goals and will refuse to relinquish decisionmaking power, which will result in conflict and paralysis. Yet, at $\mathrm{KDB}$, which has at times had over 35,000 worker members, most decisions have been, and are, made quickly and easily. How has KDB managed this?

The simple answer is that $\mathrm{KDB}$, from the outset, severely limited direct democracy-that is, a system in which every member directly participates in every decision. Workers as a whole engage in discussion and decisionmaking only within small groups, and only with respect to a subset of decisions for which discussion and deliberation among the workers is useful. KDB members accept the notion that the larger the membership, the greater the need to delegate decisionmaking to representatives (and to professionals who are monitored by the representatives). If the decisionmaking group is large and the decisions to be made are macro in scope (for example, decisions relating to the market and the overall operation of the firm), KDB uses delegation and hierarchy. This delegation, centralization, and hierarchy covers decisions such as pricing, marketing, quality control, and the purchase of raw materials. Small-group direct democracy is limited to matters relating to shop-floor production and discipline. This latter category includes numerous decisions about the operation of the work site, such as deciding on the work site's hours, seating arrangements at the site, and expenditures to improve the site. The end result is a blend of traditional corporate-style hierarchy, arrived at by worker choice and controlled by workerelected representatives, and cooperative-style shop-floor direct democracy. This system of governance is at odds with the elaborate participatory system that we were told is provided for by state law-a system that is not simply largely ignored at $\mathrm{KDB}$ but one of which the $\mathrm{KDB}$ workers and managers are essentially ignorant. ${ }^{34}$

33. For a fuller description of this background, see ISAAC ET AL., supra note 1, at 55-85.

34. In our interviews with both KDB members and government officers, we attempted on multiple occasions to obtain specifics about which rules were being followed and which were not. Perhaps understandably, neither set of respondents gave us specifics. What we did leave with, 
The effectiveness of the KDB system is best understood only with more detail. KDB is a federation of twenty-two "primary cooperatives." Each of the primary cooperatives has six to fourteen shop floors. At each, there are generally between 75 and 125 beedi rollers. Production takes place at the shop floor. Every worker directly participates, informally and continually, in the decisions about work arrangements at his or her shop floor. Each shop floor has a formal, general body meeting only about once every six months. At the general body meeting of each group of shop-floor workers (75 to 125 people) everyone participates. These meetings are the fora for discussing complaints about conditions of work, disputes with supervisors, and problems with the behavior or productivity of individual workers. Every shop floor also has a "factory committee" that does the day-to-day supervision and management of the floor. This involves deciding on matters such as ventilation, entertainment, and break times.

The workers also participate in the meetings of the separate trade unions. These trade unions are organized along political-party lines-the dominant party being the Marxist party, which is referred to as the CPM (Communist Party, Marxist). ${ }^{35}$ We mention the trade union meetings because the workers use these meetings to discuss wages and other monetary benefits (pensions, bonuses, and loans). The trade unions then negotiate wages and benefits at the central cooperative level. There is active worker participation at the trade union level. For purposes of negotiating wages, the unions form a united front. The idea of workers relying on their unions to negotiate with the entity that is conceptually theirs may seem incongruous (and does seem so to us). The sense of incongruity may be dispelled, at least to some degree, if one bears in mind that the workers have accepted a hierarchical system and that the managers, even those who have been and will

however, was a clear sense that KDB was far more hierarchical than the formal rules regarding participation suggest. Indeed, one of the primary roles that the government plays with cooperatives is to ensure that regular elections take place and that meaningful worker participation occurs. One of the stunning things about KDB, however, is that they essentially had no elections for the first twenty years of their existence. Instead, the major political parties of the state that had members at KDB would agree on a consensus slate for the central board of directors (with representation from each party), and those on the slate would be elected unopposed. Given the political makeup of the KDB worker body, however, it is clear that if real elections had been held, the Marxists would have swept the elections (over 80 percent of the workers being party sympathizers or members). In hindsight, the system that was in fact in place appears to have been vital in preventing labor disputes in that the minority factions were always kept happy. The key insight for our purposes, however, is how the government's formal rules were ignored in the KDB context.

Since 1986, regular elections have been held and the Communist Party, Marxist (CPM) has dominated. There remains, however, an alternate multiparty board with considerable power that advises the board on key matters-the Pension and Benefits Committee.

35. This is far more moderate than the name might suggest to those familiar with the Marxism associated with the former Soviet Union or China. 
again be workers, adopt a management attitude, which includes a sense of obligation to make a profit and to maintain a strong balance sheet.

In sum, while the workers do participate directly in some aspects of decisionmaking, that participation is limited to matters about which they are well-informed (such as their immediate working environment). The macro issues such as marketing strategy and policy and the overall wage and benefit structure are delegated to representatives.

That brings us to the system by which the workers select their representatives. Representatives operate at two levels above the shop floor: the primary cooperative level and the central cooperative level. The primary cooperative, as we have previously noted, includes between seven and twelve shop floors and has a board of directors elected directly by the workers. Each primary cooperative is treated as an independent profit-and-loss center. The primary cooperative's board of directors (all former beedi rollers) closely supervises the purchase of raw materials from, and sale of finished beedis to, the central cooperative. The primary cooperative's board also performs two other functions: It can make very modest expenditures (Rs 1000 ) for the improvement of working conditions, and it can settle disputes (for example, between workers and supervisors) that cannot be worked out at the shop-floor level.

All marketing, pricing, and wage decisions are made at the central cooperative level. The central cooperative has a board of directors of its own that is elected by the members of the boards of the primary cooperatives. The central board members have three-year terms. The central cooperative also makes decisions regarding wages, improvements in conditions, investment, and diversification. We discuss these aspects of the decisionmaking process in greater detail later.

What we see then is that many of the crucial decisions for KDB are made through a hierarchical governance structure. The central cooperative's board decisions are almost all a function of market demands. The members of the central board, who meet at least once a week (and typically on multiple occasions during a week), focus much of their attention on how to organize their purchases and sales to tackle the outside market for beedis. Market-driven decisions on matters such as quality, price, and production composition and levels, set strict parameters within which the direct democracy at the shop-floor level functions. Put differently, what to produce, how much to produce, and at what price to produce is decided at the top. Given these decisions and the level of technology, how to produce is determined at the primary cooperative and shop-floor level. The central board's decisions may be discussed and, on rare occasions, may even be altered at the annual general body meetings of the representatives of the primary cooperatives. 
Despite the fact that the central board's decisions almost always stand, the annual body meetings are often sites of vigorous debate. ${ }^{36}$

\section{Supervisors' Relationships with Their Worker Bosses}

As a large-scale producer, with heterogeneous workers (that' is, workers of, for example, different genders, caste, age, community, political affiliation, and skill levels), KDB needs good supervisors on the shop floor. KDB uses its supervisors to coordinate, to train, and to monitor. The standard hypothesis, however, is that supervision in a worker cooperative will be lax compared to that in a traditional capitalist firm, because the supervisors will be reluctant to adequately discipline shirking workers. The result will be a loss in productivity.

Our field study at KDB did find an unusually gentle supervisory structure. A supervisor at $\mathrm{KDB}$ does not enjoy the powers that are traditionally enjoyed by bosses. The supervisor cannot hire, fire, transfer, or even fine

36. The following table from Democracy at Work illustrates the substantial disparity in profitability that existed among the primary cooperatives in 1992-1992. ISAAC ET AL., supra note 1, at 159.

Profits Per WORKer by Primary SOCIETy 1992-1993

\begin{tabular}{llc}
\hline \multicolumn{2}{c}{ Primary Society } & $\begin{array}{c}\text { In Thousands of Rupees } \\
\text { Profit Per Employee in Rupees }\end{array}$ \\
\hline 1 & Kannur city & 2,914 \\
2 & Kannur town & 2,272 \\
3 & Azhikode & 2,161 \\
4 & Chervathur & 2,077 \\
5 & Thottada & 2,023 \\
6 & Kakkad & 1,989 \\
7 & Payyanur & 1,974 \\
8 & Chala & 1,966 \\
9 & Chirakkal & 1,957 \\
10 & Chalad & 1,820 \\
11 & Tellicherry & 1,788 \\
12 & Pinarayi & 1,730 \\
13 & Kottacherry & 1,702 \\
14 & Manjeshwar & 1,619 \\
15 & Kadirur & 1,508 \\
16 & Valiannoor & 1,497 \\
17 & Nelishwar & 1,437 \\
18 & Dharmadam & 1,205 \\
19 & Hosdurg & 1,192 \\
20 & Kasargod & 1,083 \\
21 & Bediaduka & 862 \\
22 & Badagara & 594 \\
& Average & 1,699 \\
\hline
\end{tabular}

KDB Primary Society Balance Sheets for the year ending Mar. 31, 1993, in ISAAC ET AL., supra note 1, at 159 , tbl. 6.1. 
workers. Moreover, if the worker is unhappy with the supervisor, the worker can complain to the factory committee, and the supervisor must explain his or her actions. Yet KDB's supervisory system appears to work reasonably well. Workers do listen to the supervisors. Why?

The fact is that the supervisor is not as vulnerable as the foregoing description might imply. Workers have almost no say in the hiring, firing, and wage setting for the supervisors. The central society (the top of the hierarchy) is managed by a team of professional managers who are answerable only to the central board of directors. The central society managers hire the foremen, who supervise the shop-floor supervisors (called "maistries"). These supervisors are hired not by the central cooperative managers, but rather by the primary cooperative boards. Almost all the supervisors are selected from the group of senior-most workers (who generally are also locallevel trade union functionaries). Hence, though there is a chain of command, the supervisors are not all that detached from the ranks of the ordinary workers, but at the same time are not directly beholden to them.

But what does the supervisor do (if not hiring and firing)? The supervisor's role at the shop floor is to monitor the quality and productivity of individual workers. Based on the supervisor's conclusions about worker quality, the supervisor decides on how much raw material to give to the individual workers. This is important to the workers because their wages are at least partially a function of how much they produce. The supervisor also is responsible for general discipline at the workplace-preventing or settling quarrels, making.sure that workers do not take too much time off from work, etc. Perhaps most important and most interesting, the supervisor's primary responsibility is to help train workers who are lagging in their production. The supervisor, after all, is a skilled worker. If there are workers (usually younger and newer) who are having trouble maintaining a good pace and high quality, the supervisor is supposed to work with them to improve their skills. Above the supervisors are the foremen, who conduct periodic random checks on the workplaces and send periodic reports to the central management.

But with almost no punitive powers at hand, how can the supervisor either enforce discipline or maintain productivity-especially if an entire section of the shop-floor workplace decides to shirk? Standard theory claims that workers, given relatively secure wages, will seek ways to increase their leisure. It is here that the earlier observation about the involvement in the decisionmaking process becomes relevant. That involvement appears to help overcome the temptation to shirk.

Shop-floor decisions are made with the involvement of every worker. This creates an atmosphere of heavy peer pressure. Those workers who receive lower allocations from the supervisors are noticed and often rebuked 
by their peers at meetings. In addition, the primary cooperatives that lag behind and those that perform especially well are explicitly mentioned at the annual general meetings. Given the ethos of the entire cooperative, a negative mention is considered to be acutely embarrassing, and workers either do their best to avoid negative mentions or strive to rectify the deficiency.

While there are few of the traditional direct negative incentives (such as fines or the threat of firing or of demotion), there are positive incentives. The highest productivity achievers are given special prizes and held up as models for emulation. In addition, periodic "awareness" or "education" campaigns are conducted in an effort to emphasize the importance of quality and productivity for the survival and success of the firm. These campaigns seem to support and to reinforce peer group pressures.

Thus, social pressures or norms play a key role in KDB's incentive structure. This seems to work well because of the small-group setting of the shop floor. The members of the small group of workers are generally all from the same local village, know each other well, and interact repeatedly in social settings. The puzzle is how these social pressures operate across KDB as a whole, which stretches across many villages. This puzzle takes us to the conflict between egalitarianism and individual material incentives.

\section{Egalitarianism and the Resulting Conflicts}

A distinctive feature of cooperatives is thought to be their emphasis on egalitarian compensation structures. In this respect, KDB fits the standard mold. A firm built on an egalitarian model but operating in a competitive market must expect some conflict and tension. KDB has experienced two such tensions.

The first tension has to do with the distribution of profits among the primary cooperatives. There are substantial differences in productivity among the twenty-two primary cooperatives. ${ }^{37}$ Under the present practices, however, annual bonuses are distributed uniformly as an equal percentage of wages. The bulk of the remainder of the residual is spent on improving working conditions at shop floors. This includes the construction of newer work sheds, better bathrooms, and improved ventilation. These investments are made on the basis of an assessment by the central cooperative of the needs of the various primary cooperatives (and their shop floors). This "each according to its needs" practice often causes resentment on the part of the more highly productive primary cooperatives. The resentment has often been expressed openly at the annual general body meetings. Thus far, how-

37. For a detailed explication of the structure of KDB, see ISAAC ET AL., supra note 1, at $86-155$. 
ever, the proponents of egalitarian policies have consistently prevailed. The response of the central society to the complaints has been limited to issuing strong reprimands to the laggard primary societies and to imposing closer scrutiny of the primary's operations (including more site visits by members of the central board).

A second source of tension has been the wage system itself. The wages that workers receive consist of two parts: first, a piecework component that depends entirely on the number of beedis rolled, and second, a "dearness allowance," which is a fixed sum (originally intended as an inflation adjustment). This dearness allowance-or, simply, dearness-generally amounts to almost 50 percent of the worker's daily wage. Every worker receives the dearness if he or she has rolled a minimum number of beedis. Prior to 1984, the dearness allowance was paid out in a piece-rate fashion, that is, in proportion to the number of beedis rolled. As the workforce aged, however, the older workers found it difficult to roll the minimum number in order to qualify for the dearness. Constant rolling of beedis smoothens the fingertips and reduces the grip (which is why children are considered good beedi rollers). As a result, productivity generally falls after the age of thirty-five to forty (people generally start work in their late teens or early twenties). Given the problems that the older workers were facing, and as a result of the pressure from the trade unions, the daily minimum output for entitlement to the dearness allowance was set in 1990 at eight hundred beedis a day. The explicit goal was to ensure that the older workers would be able to obtain the dearness. The hope was that the younger workers would continue to work as in the past (even though they needed to work much less in order to qualify for the dearness). This new system created a problem. The younger and often quicker workers were able to obtain close to a full day's pay with little more than half a day of work, and some even began to spend their extra time working for private firms. The average number of beedis rolled per worker declined, and the unit cost per beedi began to rise.

This situation gave rise to intense debates at all levels of the firm about the virtues of egalitarianism versus material incentive structures. There was the obvious conflict across age groups. There was also a gender dimension, because the women tended to be younger. (KDB's initial workforce had been largely made up of men; women now make up almost 50 percent of the workforce). Finally, there was a compromise. The minimum daily output requirement for entitlement to the dearness allowance was raised to nine hundred beedis a day. If a worker could not fulfill his or her quota on a particular day, however, the worker could carry his or her production over to the next day (up to the weekend). The goal was to make sure that the older workers did not lose more than a day's worth of dearness. What drove the end result was that the majority of the members of the central cooperative 
believed that the sense of solidarity among the younger workers would lead them to produce more than the minimum quotas. The conflict between egalitarianism and material incentives, however, has by no means been resolved. The debates continue on a regular basis. The central cooperative members feel that maintaining a strong egalitarian ethic is crucial to maintaining solidarity. They recognize, however, that weak incentives can result in dampened individual productivity. ${ }^{38}$

\section{E. The Accumulation Puzzle}

From an economic perspective, one of the biggest problems for a successful cooperative is that of accumulation. To the extent that a cooperative is successful and generates free cash flow, one would expect the workers to demand distribution in the form of higher wages. This does happen to some extent. But the people in control of the cooperative are committed to retention of substantial amounts to provide a safety net and for investment (which they may consider essential to long-run survival). Since such retention policies will tend to benefit future generations of workers, the current workers may demand more distribution (in the form of higher wages) and less retention.

One way of dealing with this problem is to distribute to the current workers fixed claims to future distributions. But those claims would become obligations that might defeat the objectives of retention. Another possibility is to give the current workers ownership stakes. This approach, however, only works if the older workers are allowed to market their shares or are given assurances of dividends, and therefore is likely to result in the cooperative ultimately being transformed into a capital-controlled firm. Absent such modifications, one might expect sufficient pressure from the workers that accumulation of capital will be severely limited. Investments would then require external debt financing, but this would be limited by the lack of accumulation - by the lack of an adequate equity cushion.

In contrast to this prediction, KDB's greatest success has been precisely in its capital accumulation. At KDB, the major portion of every year's residual is retained as capital or used for investment in physical assets. Today the total value of working capital and physical assets is over Rs 400 million-a staggering amount for a beedi company. Most of the workers who helped produce this surplus have now retired and have no claim to any of it. They do receive pensions, but these are fixed and minimal. And the membership policies of $\mathrm{KDB}$ give no preference to the children of existing

38. On the debates and conflicts at KDB over how egalitarian the wage structure should be, see id. at $121-25,184-88$. 
workers. ${ }^{39}$ So why haven't the workers claimed the entire surplus for themselves instead of leaving it to the next generation of workers? The first generation could have restricted membership to themselves, converted themselves into shareholders, and hired the next generation of workers as employees. That would have been the classical degeneration story.

The traditional theory assumes that workers attempt to maximize income. At least at KDB, this does not appear to be the case. The explanation seems to lie in the fact that the demand for wages at KDB-in specific contrast to beedi workers in the private sector and similarly employed workers in other sectors-is largely driven by parity concerns. In the beedi industry, as in most of the rural industries in Kerala, a government committee sets minimum wages. The term "minimum wage" is something of a misnomer because most private-sector firms ignore it. And the governmental enforcement attempts are minimal and largely ineffective. Indeed, in the case of $\mathrm{KDB}$, it was the demand by the workers that they be paid the minimum wage that led to the departure of the employers and the formation of the cooperative. Since then, KDB has always paid at least the minimum wage. In addition, the policy of the cooperative has been to regularly increase benefits such as pensions, vacation days, medical benefits, and access to loans. Indeed, these benefits, which are either largely or totally absent in the private-sector firms, constitute almost 50 percent of a KDB worker's compensation. The result is that there has been a steady improvement in the real earnings of the workers. The KDB compensation package is worth about three times what is paid by private firms. This appears to be enough to satisfy the workers.

39. Given that membership in the $\mathrm{KDB}$ is highly desired in the beedi worker community, we had expected to find at least some move at KDB towards giving an admissions preference for the children of members. We were surprised, however, to find that there had been little attempt to establish such a system of preferences (the current system is one in which a test of beedi-rolling skills is conducted and the best performers are hired). It appears, therefore, that KDB admissions operate in a purely meritocratic manner. At first we thought that this was another example of $\mathrm{KDB}$ responding to the pressures of the marketplace. That may be some of it, but there is more to the story. Specifically, the first generation of KDB workers has been successful enough to be able to provide their children significantly more in the way of education and other forms of social capital than they had. Beedi rolling is a low-status occupation, and the children of KDB workers, with their higher levels of education, are generally not interested in these jobs (this is much more true for the male children than the female children). Indeed, this is illustrated by the fact that the only part of KDB in which there is a preference given to the children of workers is the fledgling Information Technology (IT) training program. Jobs in the IT sector are prestigious, especially because these jobs are thought to have the potential to lead to jobs abroad (primarily in the Middle East), and it is telling that it is in this sector at KDB that there is some nepotism. To the extent that there has been any significant amount of concern at $\mathrm{KDB}$ about preferences in the hiring of beedi rollers, it has been about the possibility of the Marxist party using its power to give admissions preferences to its members. But our interviewees indicated that this possibility had not materialized. 
Thus, once we cease to consider workers as pure wage maximizers and instead think of wages as externally determined, the barriers to accumulation disappear. In KDB's case, the external mechanism that sets wages is the combination of the government minimum wage and the private-sector practices. The other important element in supporting accumulation is that the workers must have confidence in their management. They must trust that the managers will invest the accumulated capital in the best way possible for the assured growth of the cooperative. And, in fact, in the case of $\mathrm{KDB}$, the workers have accepted the long-term survival goals of the cooperative, and the necessary trust in management has, over time; been established.

All this, however, raises the question, how has KDB been able to provide such relatively high wages and benefits and good working conditions, and still compete with the private firms? That is the question to which we now turn.

\section{F. The Productivity Gains from a Cooperative Structure}

At the outset, we mentioned at least five possible efficiency benefits resulting from a cooperative structure: (1) happier workers working harder and better; (2) workers monitoring each other and their bosses and thus reducing shirking; (3) better health conditions at the work site resulting in fewer absences and lower turnover among workers; (4) fewer labor disputes and less need to protect against opportunistic behavior; (5) informationsharing resulting in improved decisionmaking. The fact that KDB has been able to compete successfully against its private counterparts for over thirty years (and has over 50 percent of the market share in Kerala) suggests that it is doing something right. It is less clear what exactly this is. We will begin by discussing what are not the sources of efficiency gains.

\section{Wages, Absences, and Turnover Rates}

KDB's efficiencies do not result from paying lower wages, from fewer absences, or from lower turnover rates. Take wages first. The KDB workers, who are happier because they participate in the firm's governance, do not accept lower wages in exchange for this participation right. As mentioned above, KDB not only pays its workers basic wages but also gives them health benefits, maternity benefits, pensions, and paid holidays. Costs in the beedi industry are generally calculated on a one thousand-beedi basis (in other words, how much does it cost to make one thousand beedis?). The cost of KDB's basic wages plus benefits per one thousand beedis is over three times 
that of its competitors (Rs 135-140 for one thousand beedis at KDB versus Rs $35-40$ at the other firms). 40

There is one place where KDB obtains significant wages savings, but this is not enough to explain its competitiveness. The KDB management structure is extremely thin, and the level of compensation of members of the management staff is a small fraction of what is paid by KDB's traditionally structured competitors. For example, the five members of the board of directors are essentially full-time managers of the firm. The board meets at least once a week, and the members perform a variety of managerial tasks during the remainder of the week that include purchasing raw materials, dealing with distributors, policing the markets for fake KDB beedis, and making supervisory visits to primary cooperative work sites. The compensation of the directors for such work is roughly the same as that of the beedi workers. The salaries of the top managers of a private firm of comparable size- KDB has an annual turnover in the vicinity of Rs 900 million-would be at least ten times (more likely thirty or forty times) the compensation of the KDB directors. And this is to say nothing of perks: things like a car, a driver, a housing allowance, a couple of assistants, and extensive medical coverage. The KDB directors receive nothing of the sort. Indeed, the board members and the president and secretary have only one car at their disposal (a sports utility vehicle), which they all share for work-related purposes. They took the authors to the nearby government guesthouse for lunch on one of our visits, and all seven of them piled into the vehicle. Apparently, this is how they travel when they have to go anyplace. Right next to KDB is a governmentrun cooperative (which consistently runs at a loss), and out in front one can see a long row of cars serving the various officials.

As mentioned above, $\mathrm{KDB}$ also minimizes management costs by having an extremely thin management structure. In addition to the members of the board, the president, and the secretary, KDB has only a handful of managers. This includes an office manager, an accountant, and a public relations officer. In addition, for its diversification ventures, KDB has a specific manager (the only one with an MBA, leading others to refer to him as "the MBA") and an engineer. And as with the members of the board, the salaries of these managers are dramatically lower than those paid for comparable levels of responsibility in traditional firms.

40. These are the wage costs in the informal sector, in which work is contracted out (often outside the state), and the firms do not pay anything close to the wage mandated by the Kerala government. In some cases, KDB's competitors do have subsets of workers who work directly for the main firm in a KDB-like production structure. Even in such situations, however, the wages plus benefits (the latter generally being close to zero) are no more than half of what the KDB workers earn. 
Despite the significant savings in management costs, because there are over thirty thousand workers who are paid about three times the wages of workers at competing firms, KDB's overall labor and management costs are still significantly higher than those of its competitors.

Next, consider low absentee and turnover rates. In efficiency wage theory, these are generally thought to result from healthier, happier, and betterpaid workers. We have already seen that KDB workers are highly compensated and are happy about their participation rights. As one might expect, KDB also has healthier work sites than its competitors. Indeed, the differences are dramatic. While most beedi workers work in subhuman conditions-small and dingy work sites that lack proper bathroom facilities and pose health hazards because of the way the tobacco is kept-KDB's work sites are spacious, clean, and well-ventilated and even have entertainment in the form of someone who reads stories or news articles to the workers as they are rolling beedis: Given the higher wages at KDB, workers who are happy about their participation rights, and the healthier work sites, one might have expected to see KDB's efficiency advantages to be in lower absentee and turnover rates. After all, healthy workers who like their jobs and are paid generously are likely to show up more regularly than counterparts who do not enjoy these relative advantages. This, however, is not where the bulk of KDB's efficiency gains arise. Absences are rare, and almost no one leaves KDB to join another beedi firm. But this does not produce a competitive advantage. Because almost all competing beedi production is done on an individual piecework basis, it does not much matter whether any individual works or not; there is never a shortage of beedis available to be purchased from the subcontractors. In the private beedi industry, there is no idle space or equipment.

\section{Labor Disputes, Monitoring, and Information-Sharing}

In its thirty-plus years, KDB has had no significant labor disputes. For a production facility of its size in Kerala, this is stunning. For other firms in Kerala, disputes with labor are common and can be costly. KDB's competitors in the beedi industry, however, have largely avoided this problem by a combination of moving production outside the state and using a contracting-out system, which results in a dispersed and unorganized labor force. Hence; while the lack of labor disputes is a good thing for KDB, it is not a likely source of advantage over its competitors.

At the shop-floor level, the workers engage in discussions about the day-to-day operation of the site-for example, how to structure their work hours, what improvements to make in the facilities, who will sit where, and what entertainment will be provided. Workers also discuss problems of inadequate or substandard work on the part of their fellow workers and super- 
visors. KDB's competitors have nothing of this sort. KDB's work sites, therefore, have an advantage both in information-sharing and in monitoring. Once again, however, this does not provide a significant advantage over competitors in the industry, because those competitors have adopted a strict piecework system of production. If the workers at a competing site produce less, they are paid less. If they produce more, they receive more. Assuming a fixed price for the beedis, the firm does not need to be concerned about whether monitoring or information-sharing increases productivity; productivity is, for the most part, a concern for the worker, not for the owner.

\section{Better-Quality Beedis}

$\mathrm{KDB}$ does have a decided advantage over its competitors in the uniformly higher quality of its beedis. This quality advantage is reflected in the fact that KDB's beedis sell at a significant premium over other beedis on the market. For example, a standard package of ten KDB beedis sells for Rs 2.25, whereas those of its competitors sell for between Rs 1.25 and Rs 1.75. The higher quality of the KDB beedis was confirmed by our talks with people in the area; everyone we spoke to agreed. What was more puzzling to us initially, and more difficult to understand, was the source of this quality advantage. Was it a product of the cooperative structure, and if so, what specific aspects of the cooperative structure were at work?

When we asked the workers and managers at KDB about the higherquality products, their initial explanation was that they used higher-quality raw materials. They explained that the members of the board of directors, along with a number of foremen who were quality experts, took great pains to ensure that only the best-quality tobacco and rolling leaves were used. While we did see evidence of the extreme care (bordering on obsession) that the KDB directors and foremen took in order to ensure the quality of their raw materials, this explanation is not sufficient. If the only factor that differentiated KDB beedis from those of the other manufacturers was that KDB was using higher-quality raw materials, it is hard to imagine why the competitors could not easily do the same. And with their much lower labor costs, they should be able to knock the KDB products out of the market. Indeed, it turned out that competitors had attempted to do precisely this. Hence, while $\mathrm{KDB}$ was taking great care to ensure that its workers used only highquality inputs, there had to be something else at work as well.

That something else was the rolling process itself. Specifically, there are two parts of the rolling process that are nearly impossible to monitor but that can result in low-quality beedis. The first is the wetting of the leaf prior to rolling. The tendu leaves that are used to roll the beedis have to be wet so that they can be rolled. If they aren't wet, the leaf breaks. It is important 
that the wetting is done evenly and lightly across the leaf. If it is done unevenly, the tobacco in some portions gets wetter and tastes different than in other portions of the beedi. And if there is too much wetting, the tobacco gets soggy, and the beedi becomes difficult to smoke and tastes bad. For the worker who is paid on a piecework basis, the incentives are such that he or she will likely spend minimal time being careful about wetting the leaf, because a wetter leaf is easier and quicker to roll. At the same time, it is extremely difficult to detect a beedi made with an improper wetting technique. The only way to detect a bad beedi is to actually smoke the whole beedi; one or two puffs will not reveal much. At best, the supervisors or subcontractors can do random checks.

The second key part of the rolling process as to which monitoring is difficult is in the even spreading of the tobacco. If a beedi is rolled hastily or inexpertly, the tobacco is unlikely to be spread evenly. If the tobacco isn't spread evenly, the smoker does not get an even smoke. Sometimes, if the tobacco is too thin in portions, the beedi becomes extinguished and the smoker has to relight it. Here also, the worker paid on a piecework basis has little incentive to do a proper job because ensuring an even spread takes time and monitoring is difficult. Monitoring is difficult because, again, one cannot detect whether the spread is even without smoking the entire beedi.

In sum, KDB workers appear to make up for their high wages through higher-quality production. The happier, healthier, and highly paid workers are significantly more careful with their rolling of beedis than their counterparts who roll for the private firms. At first blush, what occurs at KDB appears to fit the most often told efficiency wage story. Here, employers solve monitoring problems such as the one that KDB faces by paying workers high wages. The workers exert higher levels of effort with minimal monitoring because they fear even the small probability of losing their valuable jobs. The higher the differential between the wages paid to the workers at the firm in question and those on the labor market in general, the better the incentive structure works. Given the fact that its wages are three times those on the outside market and are highly coveted, KDB seems perfect for the standard efficiency wage story. But what occurs at KDB is quite different. Workers do not exert effort out of a fear of losing their jobs. As discussed earlier, supervisors have minimal powers to sanction workers who do not perform up to par. More salient, however, is the fact that in KDB's thirty-plus years, no one has been asked to leave. There have been one or two transfers (when there were disputes among workers), but KDB supervisors don't even think in terms of the possibility of firing someone.

To see penalties imposed for the production of bad beedis, one has to go to KDB's competitors. As discussed, monitoring quality is extremely difficult. When a subcontractor finds or suspects that a worker is producing 
substandard beedis, the worker's entire lot can be rejected. But the competitors' sticks do not appear to work nearly as well as KDB's carrots. Our repeated inquiries yielded no good explanation of why the sometimes draconian penalties were essentially insufficient to bring quality up to the KDB level.

This description may create the impression that KDB's incentive structure is all carrot and no stick, but that is not quite right. KDB's workers can be punished for poor performance in at least two important ways. The first is community pressure. $\mathrm{KDB}$ is an important institution in the Kannur region and even more so in the areas where the homes of the beedi workers tend to be clustered. Behaving in any manner that is perceived as inimical to KDB's interests generally brings strong and swift disapproval from the people in the local area. And even though bad beedis may be hard for a supervisor to detect, workers sitting side-by-side can detect a bad process of beedi rolling. Related, and perhaps more important, is the role that the Marxist party plays. At least 80 percent of KDB's workers are Marxist-party members or sympathizers. And while the party plays no official role in the operation of $\mathrm{KDB}$, its influences pervade the institution. One visible manifestation of this is that the members of the board are generally well-respected party workers. We do not know this with certainty, but we strongly suspect that workers are loathe to displease the party. The bottom line, however, is still that there is far more carrot than stick.

\section{Other Sources of Savings}

There are two additional sources of savings at KDB: a lack of corruption among top management and minimal spending on advertising and marketing.

One of the most serious problems that KDB's competitors confront is that of corruption in the purchase of raw materials. Sellers of tobacco and leaves often bribe purchasing agents to accept lower-quality raw materials. Once again, the reason this is possible is the difficulty in monitoring. A few bags of low-quality tobacco or tendu leaves can always be slipped in. At $\mathrm{KDB}$, the members of the board oversee the purchase of the leaves and tobacco, and KDB has not yet had a problem with corruption. As noted earlier, the board members not only have a long-standing dedication to the cooperative enterprise but also enjoy a high status in the community because of their rank in the KDB hierarchy. It is unlikely that a director who was found to be corrupt would be able to continue living in the area.

$\mathrm{KDB}$ is also somewhat unique in its policy of minimizing expenditures on advertising and marketing. Instead; it relies on word of mouth and reports in the newspapers. This policy obviously reduces costs but, unlike the avoidance of corruption, may result in a loss of revenue such that the net 
effect is negative. At the initial stages, when KDB's struggle against the odds was viewed as a great triumph, word of mouth and free publicity seemed to have been highly effective, but that may no longer be true, as KDB's management itself acknowledges. Despite that acknowledgement, however, there is considerable unwillingness to spend on publicity and on cultivating new markets.

The problems with the advertising and marketing strategy have revealed themselves in two product areas: first, in KDB's attempts to market its beedis in other states, and second, in its attempts to sell its new food products (produced as part of a strategy of diversification).

As to selling its beedis in other states, KDB has been unwilling to give distributors inducements to stock and to push KDB beedis. Unlike in Kerala, however, the customers in these other states are not familiar with KDB's beedis and do not ask for them. The result has been that KDB's attempts to expand its market, even in neighboring states like Tamil Nadu and Karnataka, have largely been failures.

With its new food products, the story is similar. Again, KDB has attempted to economize on the commissions that it gives distributors. The problem, however, is that the distributors are under no market pressure to buy KDB pickles, juices, coconut milk, and the like. The result is that the $\mathrm{KDB}$ is having considerable difficulty in marketing its products. This is true even in Kerala, because the potential customers for the food products, the middle-class consumers, are not the people who, as buyers of beedis, are already familiar with KDB's high standards of quality. As best we can tell, the quality of KDB's foodstuffs is exceptionally high-the obsession with highquality products has carried over from beedi production-but the unwillingness to spend on marketing and advertising has prevented KDB from breaking into these customer markets.

\section{G. Diversification}

Given its substantial accumulated capital and continuing net margins (profits), what are KDB's options? There seem to be three major possibilities: (1) improve current working conditions, (2) improve existing production technologies, and (3) diversify into other products. The standard story is that cooperative workers, because they are undiversified and have short time horizons, will focus on investing capital to preserve their own positions, but will be risk-averse and unwilling to invest in the long-term viability of the institution for the benefit of future generations. The KDB story appears to some degree to confirm this expectation. For a long time, suggestions that KDB use its accumulated capital to invest to diversify its product line were consistently rejected. It was not that there was a shortage of funds for diversification. Indeed, accumulated funds were consistently used to retire the 
debts that had been incurred at the beginning of KDB's existence. Expansion of beedi production has been financed almost entirely by retention of net earnings. The attitudes of the trade union workers and the worker representatives on the board was, why risk going into new lines of business when our traditional line of business is doing well?

In the 1990s, however, the demand for beedis (and tobacco products more generally) began to decline. The decline was attributable to (1) an overall reduction in demand, (2) an increase in the relative share of cigarettes over beedis in the tobacco market, and (3) the emergence of cheap beedis from outside the state. Employment in the cooperative began to stagnate. For the first time in three decades, employment began to decline. No one was fired, but new workers were not hired for a number of years. Finally, some workers were asked to work fewer days and hours. In response to this situation, the suggestions for diversification were revived. Proposals were presented from the top and received overwhelming support. The resulting diversification has been primarily into the food-processing industry. Interestingly, $\mathrm{KDB}$ is also setting up a technology park for information technology (IT) units and wants to train the beedi workers in the use of IT. It has even begun to use external financing in setting up these new ventures. In sum, while there do appear to be barriers to diversification and risk-taking, they are not always dispositive. ${ }^{41}$

\section{H. Degeneration}

$\mathrm{KDB}$ has been a successful cooperative for over thirty years. But will it remain so? Mainstream theory tells us that KDB's success will eventually lead to its downfall. There are at least three ways in which this could happen.

First, the managers might become bureaucratized and alienated from the workers. This is especially likely in a country like India where the government heavily promotes cooperatives and, by law, is permitted to interfere in their day-to-day functioning. The usual linkage between the typical cooperative and the government's cooperative department is such that most cooperative workers tend to view themselves as public-sector employees. A central issue in the ongoing debate in the Indian literature on cooperatives is that of how and whether to reduce the role of the government in running

41. The Indian press has remarked upon KDB's move from beedi rolling into IT, literally from one extreme end of the status and income spectrum to the other. See, e.g., T.P. Alexander, Computers to Aid Jobless Kerala Beedi-Makers, Fin. Express, Dec. 6, 1998, http:// www.expressindia.com/fe/daily/19981206/34055494.html; KDB to Diversify into Information Technology, Oct. 10, 2001, Press Trust of India Limited, 2001 WL 27849351; K.P. Sethunath, Beedi Co-op Rolls Out Software Tech Park, Fin. Express, Oct. 24, 2001, http://www.financialexpress.com/ fe20011024/efetop4.html. 
them. In the case of $\mathrm{KDB}$, after the initial government involvement in setting up the unit, the government has, in effect, given the firm special status by adopting a fairly strict hands-off practice. One reason for this, as previously suggested, seems to be that KDB has great prestige and substantial political support. Another reason is that, as if by accident, the initial government appointees were people of unusual ability, integrity, dedication, and commitment. If an ordinary government bureaucrat had been involved, $\mathrm{KDB}$ would no doubt have failed at an early stage or would have survived only with government subsidies and without all the benefits to the workers. Over time, the financial success of the cooperative has allowed it to become independent of the government.

Second, even without government interference, the managers of a successful cooperative can degenerate into an oligarchy. But KDB has its own checks and balances. The management consists of two groups. First, there are the elected board members. They are almost always chosen from the ranks of senior and highly respected workers. They take salaries that are generally the same as or lower than those of the ordinary workers. In addition, there is a norm of board members not sitting for more than a couple of terms. What one has, therefore, is board members who work extremely hard, take little in the form of direct salary, and do not develop vested interests in their positions as directors. As best we can see, the reason for this lies in the intangible rewards. Being a board member at KDB is a matter of great pride and status in the community. And that status benefit continues to accrue after retirement.

The second management group consists of the professional managers who are hired from outside for tasks such as marketing and accounting. Here, the close involvement of the worker board of directors in overseeing operations has been an important check on the tendency by the professional outsiders to seek to capture and maintain power for themselves and for their own benefit. In addition, there has always been an attempt to maintain parity between the wages of the workers and the professional managers. Obviously, there is a problem here. Hiring professional managers at worker salaries (even KDB worker salaries) means paying them much less than what the private firms are able to pay. Somehow KDB has been able to meet this challenge. We have not been able to find an explanation for how it has been able to do so.

Third, the workers themselves can become capitalists. Once they accumulate capital through a successful cooperative, what is to stop them from becoming shareholders and hiring the new workers as employees? One answer that we were given is that $\mathrm{KDB}$ has rules requiring that all workers be members of the cooperative. But these rules could be altered. After all, they are not mandated by any external body. The answer to our question appears 
to lie in the political ideology of the founding workers, but that vague notion is the best we can do.

Even accepting that, however, what guarantees a continued connection to the initial political vision? As best we can tell, there is no guarantee. The political ideology of the founders appears to have been generated largely by their struggle against the beedi business owners. The workplace itself does not appear to generate this type of political consciousness. As the newer generations of workers have become relatively successful, their links to the initial radical movements have likely diminished.

\section{CONCLUSION}

We are acutely aware of the dangers of generalizing from the experience of the $\mathrm{KDB}$ worker cooperative. It is just one case, and its initial and continuing success depended on what is perhaps a unique set of circumstances. To repeat the unique facts summarized in the introduction:

1. The process of making beedis is a simple one, requiring virtually no equipment and little coordination.

2. For KDB, marketing is also simple; it was and still is accomplished by word of mouth, in a region that at the outset was highly sympathetic to the enterprise.

3. There was at the outset a large pool of unemployed, trained workers, whose ideologies were consistent with the concept of a workercontrolled firm.

4. The firm was blessed from the start, almost by accident in some critical cases, with capable, conscientious, and honest top-level managers.

5. In a country whose economy is plagued by corrupt or inept government regulators, KDB was mostly left free of government involvement, because of the unique circumstances of its initial establishment.

Despite these unique characteristics, we offer some insights that we hope will prove valuable to other students of economic organization.

1. The KDB worker cooperative is a fine example of true worker control and worker democracy. Plainly, the workers think of KDB as theirs. At the same time, they have from the beginning accepted the need for hierarchy and delegation. That combination of democracy and delegation of authority seems to have been an essential element in KDB's success.

2. Worker cooperatives need start-up capital without giving control to the supplier of the capital. The government is probably the 
most likely source for such capital and was the source in the case of KDB.

3. When the government supplies capital, it generally imposes rules and regulations. Moreover, in Kerala there is an elaborate set of laws governing the organization and operation of cooperatives and providing for government supervision, even when there is no financial support. In the case of KDB, however, government involvement has been minimal, and the laws relating to cooperatives have been ignored in favor of a set of rules and practices tailored to the needs of KDB itself.

4. The discipline required for efficient production has been supplied in large part not by the suppliers of capital but by the product market, as well as by the workers.

5. KDB's success seems to depend importantly on the conscientiousness, dedication, and honesty of its managers. These qualities seem to be a product of (a) the method of choosing directors, through a process of active worker democracy, (b) the ideological commitment of the top managers, and $(c)$ the importance to the managers of their reputation and status in close-knit communities, characterized by people with high levels of awareness and involvement in matters relating to the firm.

6. Similarly, ideology and community norms and sanctions seem to play an important role in maintaining a high level of shop-level worker performance.

7. For the workers at $\mathrm{KDB}$, it seems that enough is enough. They are not rational maximizers who seek to squeeze out for themselves the last dollar of compensation. It is enough-perhaps even more than enough - that their compensation is high in comparison with that of beedi workers at capital-controlled firms. At the same time, they have accepted a high degree of equality in compensation throughout the entire region despite differences in productivity among individual workers and among sites in different parts of the region. ${ }^{42}$

42. According to newspaper reports, there had been an increase in beedi purchases in the United States in the late 1990s. Apparently, a segment of the young and hip crowd liked beedis. Immediately prior to the World Trade Organization meetings in Seattle, however, the United States banned beedis on account of the widespread use of child labor and other labor abuses in the beedi industry. See Ranjit Dev Raj, Beady-Eyed Giants Take Aim at India's Beedi Industry, Asta TimeS, Jan. 14, 2000, available at http://www.atimes.com/ind-pak/BA14Df01.html. An interesting aspect of this story is that KDB has made little attempt to obtain an exception from the ban (which it presumably should have been able to obtain, given the articulated reason for the ban). While this is speculation, we think that a good set of lawyers might have been able to obtain an exception for $\mathrm{KDB}$. It is difficult, however, to conceive of $\mathrm{KDB}$ being willing to spend the resources that it would take to hire lawyers for this matter. That said, we do not understand why the Indian govern- 


\section{MATCHINg THE Hypotheses to KDB'S EXPERIENCE}

\begin{tabular}{|c|c|}
\hline $\begin{array}{c}\text { Why Worker-Run Enterprises Are } \\
\text { Unlikely to Work }\end{array}$ & KDB's Experience \\
\hline $\begin{array}{l}\text { Workers are inadequately diversified. } \\
\text { This will result in their firm being exces- } \\
\text { sively conservative in its investments. }\end{array}$ & $\begin{array}{l}\text { KDB's workers are undiversified, and a } \\
\text { central goal appears to be to ensure the } \\
\text { survival of the organization. }\end{array}$ \\
\hline Workers are locked into their jobs. & $\begin{array}{l}\text { There is almost no movement out of } \mathrm{KDB} \\
\text { jobs. }\end{array}$ \\
\hline $\begin{array}{l}\text { There is no share-market discipline, and } \\
\text { this will result in shirking. }\end{array}$ & $\begin{array}{l}\text { KDB competes in a highly competitive } \\
\text { product market. This appears to impose } \\
\text { the needed amount of discipline. }\end{array}$ \\
\hline Workers are bad bosses. & $\begin{array}{l}\text { KDB has had almost no problems with } \\
\text { either shirking or corruption by managers, } \\
\text { despite the fact that the wages of KDB } \\
\text { managers are significantly lower than } \\
\text { those of managers at its competitors. }\end{array}$ \\
\hline $\begin{array}{l}\text { Workers will vote to have inefficient } \\
\text { compensation systems. }\end{array}$ & $\begin{array}{l}\text { Wages are determined as a product of } \\
\text { negotiations between the central cooper- } \\
\text { ative and the trade unions. The focus of } \\
\text { the central cooperative members is on } \\
\text { examining what market pressures will } \\
\text { allow it to pay. Workers do not vote to } \\
\text { set their own compensation }\end{array}$ \\
\hline $\begin{array}{l}\text { Workers will have heterogeneous goals, } \\
\text { and this will result in inefficiencies in } \\
\text { decisionmaking. }\end{array}$ & $\begin{array}{l}\text { Macro decisions at KDB are delegated to } \\
\text { a few representatives, and there is little } \\
\text { room for second-guessing those decisions. } \\
\text { Participatory decisionmaking does exist } \\
\text { with respect to some decisions pertaining } \\
\text { to the shop floors, but this appears to } \\
\text { result in few inefficiencies. }\end{array}$ \\
\hline $\begin{array}{l}\text { Workers will face difficulties in raising } \\
\text { capital (especially at the outset). }\end{array}$ & $\begin{array}{l}\text { KDB had government funding at the out- } \\
\text { set. Subsequently, KDB has relied almost } \\
\text { exclusively on self-financing. At least } \\
\text { today, based on its success over the past } \\
\text { four decades, KDB could easily find exter- } \\
\text { nal financing. But it has done so only to } \\
\text { a very limited extent. }\end{array}$ \\
\hline $\begin{array}{l}\text { Workers will shirk and not provide ade- } \\
\text { quate monitoring. }\end{array}$ & $\begin{array}{l}\text { KDB has a highly egalitarian compensa- } \\
\text { tion structure, and it is likely that there is } \\
\text { at least some shirking with respect to the } \\
\text { quantity of beedis produced (by the } \\
\text { younger and most productive workers). } \\
\text { Nevertheless, there appears to be an } \\
\text { effective monitoring system that ensures } \\
\text { high-quality production. }\end{array}$ \\
\hline
\end{tabular}

ment did not obtain (or at least ask for) an exception for KDB. We are grateful to Heidi Li Feldman for this point. 


\begin{tabular}{|l|l|}
\hline $\begin{array}{l}\text { Why There Will Not Be Accumulation and } \\
\text { Why There Will Be Degeneration Instead }\end{array}$ & \multicolumn{1}{|c|}{ KDB's Experience } \\
\hline $\begin{array}{l}\text { If the worker-run enterprise prospers and } \\
\text { accumulates capital, the members will be } \\
\text { reluctant to share that capital with new } \\
\text { members. Hence, either the capital will } \\
\text { be distributed to the first set of workers, } \\
\text { or the new entrants will be employees (as } \\
\text { opposed to members). }\end{array}$ & $\begin{array}{l}\text { KDB has had an extremely high level of } \\
\text { capital accumulation. Membership drives } \\
\text { are conducted in a cyclical pattern, and } \\
\text { new members are taken on only when } \\
\text { times are good and capital accumulation } \\
\text { levels are high. }\end{array}$ \\
\hline $\begin{array}{l}\text { Workers will focus on removing as much } \\
\text { capital as possible before they retire and } \\
\text { will be reluctant to make investments if } \\
\text { the benefits primarily accrue to later gen- } \\
\text { erations of workers. }\end{array}$ & $\begin{array}{l}\text { One of the primary concerns of KDB's } \\
\text { members (especially those on the board of } \\
\text { directors) is the long-term survival of the } \\
\text { enterprise. Hence, long-term invest- } \\
\text { ments that are seen as furthering that } \\
\text { goal are often made. }\end{array}$ \\
\hline $\begin{array}{l}\text { The second (and future) generation of } \\
\text { workers will lack ideology and commit- } \\
\text { ment. }\end{array}$ & $\begin{array}{l}\text { There does appear to be a diminution in } \\
\text { ideology and commitment. But the } \\
\text { effects of this are not clear as yet. }\end{array}$ \\
\hline
\end{tabular}

\begin{tabular}{|l|l|}
\hline Where Will We Find Worker Cooperatives & \multicolumn{1}{|c|}{ KDB's Experience } \\
\hline $\begin{array}{l}\text { Worker cooperative will be clustered in a } \\
\text { few industries. }\end{array}$ & $\begin{array}{l}\text { KDB appears to be the only large and suc- } \\
\text { cessful worker cooperative in the beedi } \\
\text { industry. }\end{array}$ \\
\hline $\begin{array}{l}\text { Worker cooperatives will be found in } \\
\text { regions where the local culture is condu- } \\
\text { cive to a cooperative-like organization. }\end{array}$ & $\begin{array}{l}\text { Kerala has a strong leftist culture. But it } \\
\text { has proved nearly impossible to replicate } \\
\text { KDB's success. }\end{array}$ \\
\hline
\end{tabular}

\begin{tabular}{|l|l|}
\hline \multicolumn{1}{|c|}{$\begin{array}{c}\text { Why Cooperatives May Produce } \\
\text { Efficiency Gains }\end{array}$} & \multicolumn{1}{c|}{ KDB's Experience } \\
\hline $\begin{array}{l}\text { Happier workers will exert higher levels } \\
\text { of effort. }\end{array}$ & $\begin{array}{l}\text { It is hard to say. KDB workers do exert } \\
\text { high levels of effort. But it is not clear } \\
\text { that these high effort levels are a result of } \\
\text { high levels of happiness or job satisfac- } \\
\text { tion. }\end{array}$ \\
\hline $\begin{array}{l}\text { There will heightened levels of mutual } \\
\text { monitoring. }\end{array}$ & Unambiguously true. \\
\hline $\begin{array}{l}\text { Health conditions at a worker coopera- } \\
\text { tive will be better than those at the capi- } \\
\text { talist firms, and the result will be lower } \\
\text { rates of turnover and absenteeism. }\end{array}$ & $\begin{array}{l}\text { Health conditions at KDB are much bet- } \\
\text { ter than those at its capitalist counter- } \\
\text { Karts. But it is not clear that this benefits } \\
\text { KDB's efficiency levels. }\end{array}$ \\
\hline $\begin{array}{l}\text { There will be less fear of opportunistic } \\
\text { behavior, and the result will be fewer } \\
\text { labor disputes. }\end{array}$ & $\begin{array}{l}\text { KDB has had almost no labor disputes, } \\
\text { while the capitalist firms in the region } \\
\text { have been beset by such problems. }\end{array}$ \\
\hline
\end{tabular}

